\title{
FAREWEll to A COLlEAgue AND FRIEND of HTS
}

Author:

Johan Buitendag ${ }^{1,2}$

\section{Affiliations: \\ ${ }^{1}$ Chairperson of the}

Editorial Board

${ }^{2}$ Department of Systematic

Theology and Christian

Ethics, University of

Pretoria, South Africa

Correspondence to:

Johan Buitendag

e-mail:

johan.buitendag@up.ac.za

Postal address:

Faculty of Theology,

University of Pretoria

Pretoria 0002, South

Africa

\section{Keywords:}

P.J. van der Merwe; retirement; University

of Pretoria; Faculty of

Theology; Department of

Science of Religion and

Missiology

Dates:

Received: 14 Sept. 2009

Accepted: 02 Nov. 2009

Published: 11 Dec. 2009

How to cite this article:

Buitendag, J., 2009,

'Farewell to a colleague

and friend of HTS',

HTS Teologiese Studies/

Theological Studies 65(1),

Art. 766, 4 pages. DOI:

10.4102/hts.v65i1.766

This article is available at:

http://www.hts.org.za

C) 2009. The Authors. Licensee: OpenJournals Publishing. This work is licensed under the Creative Commons

Attribution License.

Opgedra aan prof. dr P.J. van der Merwe bygeleentheid van aanvaarding van emeritaat 31 Desember 2009. Dit is vir die redaksie 'n voorreg en eer om hierdie uitgawe van die HTS Teologiese Studies aan sy langsdienende lid, Pieter Johannes van der Merwe, op te dra. Hy tree op 31 Desember 2009 by die Universiteit van Pretoria af in die posisie van Professor en Hoof van die Departement Godsdiensen Sendingwetenskap in die Fakulteit Teologie. 'n Posisie wat hy sedert 1979 in Afdeling A van die destydse Fakulteit en sedert 1 Januarie 2000 in die gesamentlike Fakulteit beklee het.

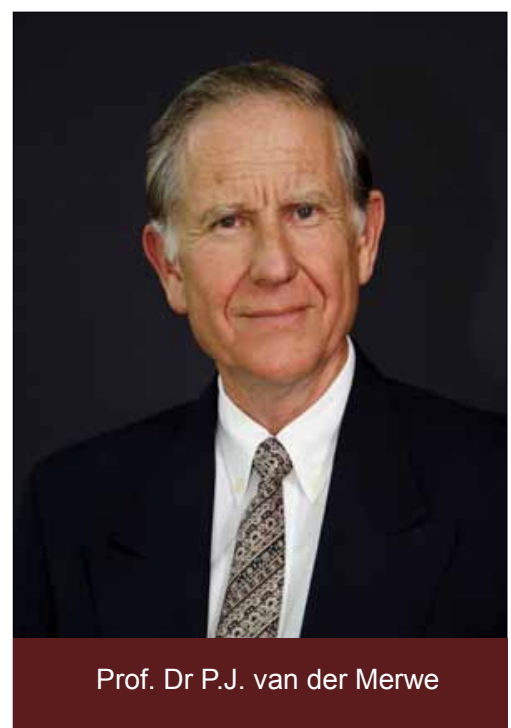

Dedicated to Prof. Dr P.J. van der Merwe on the occasion of his retirement on 31 December 2009. This issue of HTS Theological Studies/Teologiese Studies is dedicated to the longest serving member of the editorial team, Pieter Johannes van der Merwe, who retires on 31 December 2009 as Professor and Head of the Department of Science of Religion and Missiology in the Faculty of Theology, University of Pretoria - a position he has held since 1979, initially in Section A of the former Faculty, and in the joint Faculty since 1 January 2000.

Piet van der Merwe was born on 24 August 1944 and matriculated at the

Piet is op 24 Augustus 1944 gebore en matrikuleer in 1962 aan die Afrikaanse Hoër Seunskool in Pretoria. Hy behaal agtereenvolgens die volgende kwalifikasies aan die Universiteit van Pretoria: Baccalaureus Artium (1965), Baccalaureus Divinitatis (1968), Baccalaureus Honores in Klassieke Tale (1969), Doctor Divinitatis in Godsdiens- en Sendingwetenskap (1978) en die Diploma in Tersiêre Onderrig (1984).

Op 21 Junie 1970 word hy as predikant van die Nederduitsch Hervormde Kerk van Afrika in die gemeente Premiermyn georden, waarna hy tussen die jare 1972 en 1979 ook die gemeente Witfontein deeltyds bedien het. Sy kerklike betrokkenheid was dwarsdeur sy loopbaan van hoë gehalte. Hy het in verskeie sinodale rade van die Kerk gedien, waarvan die bekendste die Raad vir Apostolaat en die Raad vir Godsdienste was. Hy was ook jare lank voorsitter van laasgenoemde raad. Voorts dien hy ook lank in die redaksie van Die Hervormer, lyfblad van die NHKA, waar hy vormende invloed uitgeoefen het. Hy sal ook onthou word as die persoon wat die basis gelê het vir die huidige e-Hervormer met sy bekende 'Nuusbrokkies' wat hy destyds behartig het.

Sy vermoë om feitelik en akkuraat te formuleer, gepaardgaande met sy organisatoriese vermoë en rekenaarvaardigheid, het meegebring dat Piet 'n gewilde keuse as sekretaris vir vergaderings was. As sekretaris van die onderhandelings tussen die betrokke kerke en die Universiteit op pad na die gesamentlike Fakulteit Teologie in die jaar 2000, het hy groot respek by alle betrokke partye afgedwing. Dit het meegebring dat hy die vanselfsprekende keuse vir sekretaris ook by die latere twee onderhandelings (2003/4 en 2008/9) was. In die Fakulteit Teologie was hy onder andere ook sekretaris van die Dagbestuur, die Onderrig- en Programmekomitee, die Hervormde Dosentevergadering en die Forum for University Theological Education (FUTE), waar sy werk deurgaans groot waardering ontlok het. Sy rustige en gebalanseerde bydraes in vergaderings en debatte het ook altyd tot kalmte en insig gelei.
Afrikaanse Hoër Seunskool in Pretoria in 1962. He commenced his studies at the University of Pretoria and obtained the following qualifications: Baccalaureus Artium (1965), Baccalaureus Divinitatis (1968), Baccalaureus Honores in Classics (1969), Doctor Divinitatis in Science of Religion and Missiology (1978), and the Diploma in Tertiary Education (1984).

On 21 June 1970 he was ordained as minister of the Netherdutch Reformed Church of Africa in the Premiermyn congregation. From 1972 to 1979 he served as part-time minister of the Witfontein congregation. Throughout his academic career he remained fully engaged in the church. He served on various synodal councils, notably the Council for Apostolate and the Council for Religions of which he officiated as chairperson for many years. He served on the editorial board of Die Hervormer, mouthpiece of the Netherdutch Reformed Church in Africa, where he played a leading role in shaping the publication. $\mathrm{He}$ will also be remembered for his electronic news bulletin, 'Nuusbrokkies', which paved the way for the e-Hervormer, which is at present the official electronic news bulletin of the Church.

His gift for factual and accurate formulation, combined with his organisational ability and computer skills, made Piet a popular choice for the secretariat of various bodies. He performed this task exceptionally well during the process of negotiations between the relevant churches, which eventually led to the establishment of the joint Faculty of Theology in the year 2000. He was assigned this task again for the negotiations of 2003/4 and 2008/9. Within the Faculty of Theology he was appointed to the secretariat of the Executive, the Education and Programmes Committee, the Nederduitsch Hervormde Lecturers' Council of the Faculty of Theology of the University of Pretoria, and on a national level of the Forum for University Theological Education (FUTE), where his work was always greatly appreciated. In meetings and discussions his sober and balanced contributions provided insight and often helped to steady the deliberations. 
Alhoewel die klassieke studies deurgaans sy belangstelling gebly het en hy vroeg in sy loopbaan téén die moontlikheid gekies het om 'n loopbaan in Latynstudies te volg, was hy sedert sy studentejare primêr geïnteresseerd in die Godsdienswetenskap. Gedurende die jare 1971 tot 1978 was hy senior lektor in Godsdienswetenskap aan die Universiteit van Suid-Afrika (UNISA) en vanaf 1979 tot 2009 professor en hoof van hierdie vakgebied se department aan die Universiteit van Pretoria (UP) Hy skryf reeds sy B.D. -skripsie in 1968 in hierdie vakgebied en wel oor die onderwerp, Vergelykende studie tussen die Isisen Maria-Kultus. Hierna volg sy proefskrif in 1977 met as titel, Die Godsdienste by Vaticanum II en dit weer, kulmineer in sy professorale intreerede by die Universiteit van Pretoria in 1979 met die tema, Die Godsdiens as probleem vir die Godsdienswetenskap en die Teologie (Van Schaik 1979).

Piet het hoofsaaklik van die HTS Teologiese Studies gebruik gemaak as die vakwetenskaplike tydskrif van keuse vir sy publikasies. Hierin publiseer hy nie minder as twee en twintig geakkrediteerde artikels nie waarvan enkeles mét (of ás) ' $n$ mede-outeur. Die volgende artikels het gedurende sy loopbaan in verskillende geakkrediteerde joernale verskyn:

1. Van der Merwe, P.J., 1973, 'Die krisis in die moderne godsdienswetenskap', Theologica Evangelica 6(1), 56-68.

2. Van der Merwe, P.J., 1976, 'Die Christendom in die wêreldgeskiedenis', Theologica evangelica 9(2\&3), 187-194.

3. Van der Merwe, P.J., 1978, 'Die uitspraak van die Tweede Vatikaanse Konsilie oor die Jode - 'n kommentaar. Deel 1', Theologica evangelica 11(1), 62-71.

4. Van der Merwe, P.J., 1978, 'Die uitspraak van die Tweede Vatikaanskonsilie oor die Jode - 'n kommentaar. Deel 2', Theologica evangelica 11(2), 34-41.

5. Van der Merwe, P.J., 1983, 'Die BD-graadkursus aan UP en die keuse tussen teologiese - of predikantsopleiding - ' $n$ blik vanuit die Nederduitsch Hervormde Kerk', Skrif en Kerk 4(1), 69-74.

6. Van der Merwe, P.J., 1984, 'Teologiese opleiding en kurrikulum-ondersoek', HTS Teologiese Studies/Theological Studies 40(1), 141-146.

7. Van der Merwe, P.J., 1984, ‘Doop, sending en die opkoms van die juridiese kerkbegrip', HTS Teologiese Studies/Theological Studies 40(3), 62-67.

8. Van der Merwe, P.J., 1985, 'Godsdienswetenskaplike aspek van die teologie', HTS Teologiese Studies/Theological Studies 41(4), 511-518.

9. Van der Merwe, P.J., 1986, ‘RGN-Verslag oor godsdiens, tussengroepverhoudinge en maatskaplike verandering in SA', HTS Teologiese Studies/Theological Studies 42(3), 564-579.

10. Van der Merwe, P.J., 1987, 'Wonder en wondervertelling gesien teen die agtergrond van mite en ontmitologisering', HTS Teologiese Studies/Theological Studies 43(1\&2), 192-204.

11. Van der Merwe, P.J., 1989, 'Paradigmas en progressie in die teologie: 'n Perspektief op die RGN-kongres van April 1988, HTS Teologiese Studies/Theological Studies 45(2), 192-204.

12. Van der Merwe, P.J., 1989, 'Prof. dr. F J van Zyl as mens, kerkman en godsdiensfilosoof', HTS Teologiese Studies/ Theological Studies 45(2), 231-252.

13. Van der Merwe, P.J., 1990, 'Nederduitsch Hervormde Kerk en sy bediening in ' $n$ toekomstige Suid-Afrika: Die visie van "Kerk en Wêreld 2000"', HTS Teologiese Studies/Theological Studies 46(4), 672-689.

14. Van der Merwe, P.J., 1992, 'Resente geskiedenis en ontwikkeling van die Departement Godsdiens- en Sendingwetenskap (Afd A), 1979-1992', HTS Teologiese Studies/Theological Studies 48(1\&2), 476-507.

15. Van der Merwe, P.J. \& Crafford, D., 1992, 'Departement Godsdiens- en Sendingwetenskap (Afd A), Universiteit van Pretoria, 1917-1978', HTS Teologiese Studies/Theological Studies 48(1\&2), 564-579.

16. Taljard, D.J. \& Van der Merwe, P.J., 1993, ‘Enkele grondbeskouings van Johanna Brandt se denke', HTS Teologiese Studies/Theological Studies 49(1\&2), 267-280.
Although the Classics had always been his special interest, he early on decided against a career in Latin Studies and chose Science of Religion instead, which has been his prime interest since his student days. From 1971 to 1978 he was senior lecturer in Science of Religion at the University of South Africa (UNISA), and from 1979 to 2009 professor and head of the Department of Science of Religion at the University of Pretoria (UP). In 1968, he chose this field of study for his BD dissertation, the topic being a comparative study of the Isis and Mary cults (Afrikaans title: Vergelykende studie tussen die Isis- en Maria-Kultus). This was followed by a thesis in 1977 on the religions at Vaticanum II (Afrikaans title: Die Godsdienste by Vaticanum II). In 1979 he delivered his inaugural lecture at the University of Pretoria on the theme of religion as a problem for Science of Religion and Theology (Afrikaans title: Die Godsdiens as probleem vir die Godsdienswetenskap en die Teologie, published by Van Schaik 1979).

Over the years Piet has shown a preference for HTS Theological Studies/Teologiese Studies for the publication of his articles, and has published 22 accredited articles in this journal, some of which along with a co-author or as co-author. A list of articles published during the course of his career is the following:

1. Van der Merwe, P.J., 1973, 'Die krisis in die moderne godsdienswetenskap', Theologica Evangelica 6(1), 56-68.

2. Van der Merwe, P.J., 1976, 'Die Christendom in die wêreldgeskiedenis', Theologica evangelica 9(2\&3), 187-194.

3. Van der Merwe, P.J., 1978, 'Die uitspraak van die Tweede Vatikaanse Konsilie oor die Jode - 'n kommentaar. Deel 1', Theologica evangelica 11(1), 62-71.

4. Van der Merwe, P.J., 1978, 'Die uitspraak van die Tweede Vatikaanskonsilie oor die Jode - 'n kommentaar. Deel 2', Theologica evangelica 11(2), 34-41.

5. Van der Merwe, P.J., 1983, 'Die BD-graadkursus aan UP en die keuse tussen teologiese - of predikantsopleiding - ' $n$ blik vanuit die Nederduitsch Hervormde Kerk', Skrifen Kerk 4(1), 69-74.

6. Van der Merwe, P.J., 1984, 'Teologiese opleiding en kurrikulum-ondersoek', HTS Teologiese Studies/Theological Studies 40(1), 141-146.

7. Van der Merwe, P.J., 1984, 'Doop, sending en die opkoms van die juridiese kerkbegrip', HTS Teologiese Studies/Theological Studies 40(3), 62-67.

8. Van der Merwe, P.J., 1985, 'Godsdienswetenskaplike aspek van die teologie', HTS Teologiese Studies/Theological Studies 41(4), 511-518.

9. Van der Merwe, P.J., 1986, 'RGN-Verslag oor godsdiens, tussengroepverhoudinge en maatskaplike verandering in SA', HTS Teologiese Studies/Theological Studies 42(3), 564-579.

10. Van der Merwe, P.J., 1987, 'Wonder en wondervertelling gesien teen die agtergrond van mite en ontmitologisering', HTS Teologiese Studies/Theological Studies 43(1\&2), 192-204.

11. Van der Merwe, P.J., 1989, 'Paradigmas en progressie in die teologie: 'n Perspektief op die RGN-kongres van April 1988, HTS Teologiese Studies/Theological Studies 45(2), 192-204.

12. Van der Merwe, P.J., 1989, 'Prof. dr. F J van Zyl as mens, kerkman en godsdiensfilosoof', HTS Teologiese Studies/ Theological Studies 45(2), 231-252.

13. Van der Merwe, P.J., 1990, 'Nederduitsch Hervormde Kerk en sy bediening in ' $n$ toekomstige Suid-Afrika: Die visie van "Kerk en Wêreld 2000"', HTS Teologiese Studies/Theological Studies 46(4), 672-689.

14. Van der Merwe, P.J., 1992, 'Resente geskiedenis en ontwikkeling van die Departement Godsdiens- en Sendingwetenskap (Afd A), 1979-1992', HTS Teologiese Studies/Theological Studies 48(1\&2), 476-507.

15. Van der Merwe, P.J. \& Crafford, D., 1992, 'Departement Godsdiens- en Sendingwetenskap (Afd A), Universiteit van Pretoria, 1917-1978', HTS Teologiese Studies/Theological Studies 48(1\&2), 564-579.

16. Taljard, D.J. \& Van der Merwe, P.J., 1993, 'Enkele grondbeskouings van Johanna Brandt se denke', HTS Teologiese Studies/Theological Studies 49(1\&2), 267-280. 
17. Van der Merwe, P.J., 1994, 'Oorreding in evangelisasie', HTS Teologiese Studies/Theological Studies 50(1\&2), 423-453.

18. Swanepoel, P.C. \& Van der Merwe, P.J., 1996, ‘Evangeliserende gemeente: 'n Leefwyse? 'n Besinning oor missionere gerigtheid as aspek van gemeentewees', HTS Teologiese Studies/Theological Studies 52(2\&3), 449-475.

19. Van der Merwe, P.J., 1996, 'Kerk en Kultuur - 'n godsdiensteologiese perspektief', HTS Teologiese Studies/Theological Studies 52(4), 671-692.

20. Van der Merwe, P.J. \& Van Wyk, D.J., 1992, 'Francois Jacobus van Zyl, hoogleraar 1960-1978', HTS Teologiese Studies/Theological Studies 48(1\&2), 381-405.

21. Geyser, A. \& Van der Merwe, P.J., 1997, ‘Van der Leeuw en Noordmans oor Teologie: Godsdienswetenskaplike agtergronde van die gesprek', HTS Teologiese Studies/ Theological Studies 53(1\&2), 372-392.

22. Van der Merwe, P.J., 1997, 'Inheemswording en inkulturasie: Implikasie vir teologie en kerk', HTS Teologiese Studies/ Theological Studies 53(4), 1376-1398.

23. Van der Merwe, P.J., 1999, 'Prof Dr L J S Steenkamp: 'n Oorsig van sy lewe en werk,' HTS Teologiese Studies/ Theological Studies 55(2\&3), 305-321.

24. Van der Merwe, P.J., 2000, 'Prof Dr J H Koekemoer as kerkman en akademikus', HTS Teologiese Studies/Theological Studies 56(2\&3), 335-351.

25. Van der Merwe, P.J., 2005, 'Church and culture: A religiotheological perspective', HTS Teologiese Studies/Theological Studies 61(3), 771-791.

26. Van der Merwe, P.J., 2008, 'The contribution of the Netherdutch Reformed Church of Africa (NHKA) to theological training at the Transvaal University College', HTS Teologiese Studies/Theological Studies 64(1), 27-48.

27. Bae, C.S. \& Van der Merwe, P.J., 2008, 'Ancestor worship is it Biblical?, HTS Teologiese Studies/Theological Studies 64(3), 1299-1325.

Indien'n mens die temas ontleed waaroor Piet die afgelope veertig jaar nagevors en geskryf het, bemerk 'n mens die verskeidenheid van sy belangstelling en akademiese betrokkenheid. Op die Universiteit van Pretoria se webblad toon hy in die jaar van sy aftrede sy navorsingsvelde aan as die teologie van godsdiens, die sending van die NHKA, Christelike antisemitisme en laastens, sake van kerk en maatskappy. Veral aan laasgenoemde aspek gee hy baie aandag. Die groot oorwig van artikels dien dan ook hierdie aspek. Opmerklik is dat minstens drie artikels in bogenoemde lys, oor die teologiese opleiding aan UP gaan. Kurrikulumondersoek het hom gevolglik ook deurgaans na aan die hart gelê. Dit dien spesifiek vermeld te word dat hy aan prof. F.J. van Zyl, sy hooggewaardeerde leermeester en mentor tot aan dié se dood, twee vollengte artikels in die HTS gewy het en 'n verdere twee populêre artikels onderskeidelik in die Konteks $(14 / 12,2003)$ en die Almanak $(86,1992)$ van die NHKA oor prof. F.J. van Zyl laat publiseer het. (Hy het wel ook twee ander biografiese artikels laat verskyn, te wete die oor prof. J.H. Koekemoer en prof. L.J.S. Steenkamp onderskeidelik.) Dit is ook opvallend dat nadat hy 1979 by die Universiteit van Pretoria aangestel is, hy eerste in die Skrif en Kerk (1983), die NGK se tydskrif aan UP en eers die daaropvolgende jaar in HTS (1984), die NHKA se tydskrif aan UP, publiseer. Albei die artikels handel ook oor dieselfde saak, te wete teologiese opleiding.

Twee direkte afleidings is hieruit belangrik: Piet is 'n ekumeniese mens en ander kerke se kollegas het deurgaans groot waardering vir sy gesindheid en optrede gehad. Tweedens kan ook duidelik hieruit afgelei word watter belangrike plek teologiese opleiding en kurrikulering in sy persoonlike akademiese ondersoek gekry het. Geen wonder dat hy ook 'n sleutelrol in die kurrikulêre herstrukturering van die nuwe fakulteit se programme gespeel het nie en tans betrokke is by hernuwing en herstrukturering van die fakulteit se voorgraadse programme.

Alhoewel Piet geen monografie uitgegee het nie, was hy saam met ondergetekende medeouteur van 'n boek oor die New Age
17. Van der Merwe, P.J., 1994, 'Oorreding in evangelisasie', HTS Teologiese Studies/Theological Studies 50(1\&2), 423-453.

18. Swanepoel, P.C. \& Van der Merwe, P.J., 1996, 'Evangeliserende gemeente: 'n Leefwyse? 'n Besinning oor missionere gerigtheid as aspek van gemeentewees', HTS Teologiese Studies/Theological Studies 52(2\&3), 449-475.

19. Van der Merwe, P.J., 1996, 'Kerk en Kultuur - 'n godsdiensteologiese perspektief', HTS Teologiese Studies/Theological Studies 52(4), 671-692.

20. Van der Merwe, P.J. \& Van Wyk, D.J., 1992, 'Francois Jacobus van Zyl, hoogleraar 1960-1978', HTS Teologiese Studies/Theological Studies 48(1\&2), 381-405.

21. Geyser, A. \& Van der Merwe, P.J., 1997, ‘Van der Leeuw en Noordmans oor Teologie: Godsdienswetenskaplike agtergronde van die gesprek', HTS Teologiese Studies/ Theological Studies 53(1\&2), 372-392.

22. Van der Merwe, P.J., 1997, 'Inheemswording en inkulturasie: Implikasie vir teologie en kerk', HTS Teologiese Studies/ Theological Studies 53(4), 1376-1398.

23. Van der Merwe, P.J., 1999, 'Prof Dr L J S Steenkamp: 'n Oorsig van sy lewe en werk,' HTS Teologiese Studies/ Theological Studies 55(2\&3), 305-321.

24. Van der Merwe, P.J., 2000, 'Prof Dr J H Koekemoer as kerkman en akademikus', HTS Teologiese Studies/Theological Studies 56(2\&3), 335-351.

25. Van der Merwe, P.J., 2005, 'Church and culture: A religiotheological perspective', HTS Teologiese Studies/Theological Studies 61(3), 771-791.

26. Van der Merwe, P.J., 2008, 'The contribution of the Netherdutch Reformed Church of Africa (NHKA) to theological training at the Transvaal University College', HTS Teologiese Studies/Theological Studies 64(1), 27-48.

27. Bae, C.S. \& Van der Merwe, P.J., 2008, 'Ancestor worship is it Biblical?, HTS Teologiese Studies/Theological Studies 64(3), 1299-1325.

The themes of Piet's research and writings over the past forty years indicate a variety of interests and a broad range of academic involvement. His research interests as indicated on the University of Pretoria's website in 2009, the year of his retirement, include theology of religion, the Netherdutch Reformed Church's mission, Christian anti-Semitism and finally, the church and social issues. The majority of his articles focused on the latter. It is noteworthy that at least three articles deal specifically with theological training at UP. It follows that curriculum investigation has always been close to his heart. He dedicated two articles in the HTS Theological Studies/Teologiese Studies to Prof. F.J. van Zyl, his highly regarded teacher and mentor. He also published two popular articles on Prof. F.J. van Zyl in Konteks $(14 / 12,2003)$ and in Almanak $(86,1992)$, publications of the Netherdutch Reformed Church of Africa. Two further biographical articles, namely on Prof. J. H. Koekemoer and Prof. L.J.S. Steenkamp respectively were published by him. After his appointment at the University of Pretoria in 1979, he first published in the journal of the Dutch Reformed Church, Skrif en Kerk (1983), but in the next year in 1984 he published in HTS Theological Studies/Teologiese Studies, the journal of the NHKA at UP. Notably, his first two articles deal with the subject of theological training.

What can be inferred from the above is that Piet is ecumenical at heart. Throughout his career he was also highly regarded by colleagues from other churches. Secondly, his emphasis on theological training and curriculum studies during his academic career is apparent. He therefore also played a key role in the present restructuring of the curriculum for the Faculty's undergraduate program.

Although Piet did not publish a monograph, he co-authored a book on the New Age (CUM Books, 1991) with myself, and a book on science of religion and African religions (ISWEN, 1994) with Professor D. Crafford. He also contributed chapters to the following collections:

1. Van der Merwe, P.J., 1978, 'Godsdienswetenskap', in I.H. Eybers (ed.), Inleiding in die teologie (NG Kerkboekhandel). 
(CUM Boeke 1991) en saam met prof. D. Crafford gee hy weer 'n boek uit oor godsdienskunde en die tradisionele godsdienste van Afrika (ISWEN, 1994). Hy het hoofstukke in die volgende boeke geskryf:

1. Van der Merwe, P.J., 1978, 'Godsdienswetenskap', in I.H. Eybers (red.), Inleiding in die teologie (NG Kerkboekhandel).

2. Van der Merwe, P.J., 1981, 'Burgerlike godsdiens in SuidAfrika - teologies en godsdienswetenskaplik beskou', in S.J. Botha, Kerk in die wêreld, HAUM Pretoria.

3. Van der Merwe, P.J., 1981, 'Response to JS Kruger, The concept religion a dimensional clarification', Proceedings of the 5th Symposium of the Institute for Theological Research, UNISA, Pretoria.

4. Van der Merwe, P.J., 1991, 'Sionisme en die staat Israel', in W.C. Van Wyk (red.), Ons Joodse bure, KITAL, Pretoria.

Dit is duidelik dat Piet in die beoefening van sy akademiese navorsing deurgaans moeite gedoen het om die resultate van sy ondersoek in die kerk te dissemineer. Sy publikasies van populêre aard wat hoofsaaklik in Die Hervormer en Konteks verskyn het, toon ook die wye veld aan wat gedek word. In hierdie twee lyfblaaie skryf hy gedurende die laaste dertig jaar amper ' $n$ honderd artikels. Dit wissel van gewoon net nuus uit die Fakulteit tot die jongste ontwikkelinge in sy vakgebied. Hy dek 'n terrein wat onder andere sake soos die onderwys, etiek en selfs die natuurwetenskappe insluit. Ondergetekende is bereid om te konstateer dat Piet een van die kollegas van die Fakulteit was wat die wydste algemene kennis het. Hy kan oor haas enige saak met betreklike detail praat.

Dit was tot groot vreugde van sy kollegas dat hy aangekondig het dat hy en Riekie van der Walt verloof is en gedurende 2010 in die huwelik gaan tree. Die mense wat na aan Piet lewe en die vibrasies van sy emosies optel, weet wat Riekie die afgelope meer as vyf jaar vir hom beteken het. Ons weet dat hulle 'n baie gelukkige en mooi huwelik tegemoetgaan.

Ons groet met hierdie uitgawe van die HTS 'n kollega en vriend wat diep spore by sowel die Universiteit van Pretoria as die Nederduitsch Hervormde Kerk getrap het. Hy dra die agting en waardering van elkeen wat met hom 'n stuk pad meegemaak het. Ons wil hom derhalwe graag vir hierdie volgende fase van sy lewe, die Aäronitiese seënbede toewens:

Die HERE sal jou seën en jou behoed;

die HERE sal sy aangesig oor jou laat skyn en jou genadig wees; die HERE sal sy aangesig oor jou verhef en aan jou vrede gee.

Johan Buitendag

Voorsitter van die Redaksie
2. Van der Merwe, P.J., 1981, 'Burgerlike godsdiens in SuidAfrika - teologies en godsdienswetenskaplik beskou', in S.J. Botha, Kerk in die wêreld, HAUM Pretoria.

3. Van der Merwe, P.J., 1981, 'Response to JS Kruger, The concept religion a dimensional clarification', Proceedings of the 5th Symposium of the Institute for Theological Research, UNISA, Pretoria.

4. Van der Merwe, P.J., 1991, 'Sionisme en die staat Israel', in W.C. Van Wyk (ed.), Ons Joodse bure, KITAL, Pretoria.

Piet was always committed to disseminating his research results to the church. Popular articles appeared mainly in the two publications of the church, Die Hervormer and Konteks. These nearly 100 articles are indicative of the broad field of research he has covered over a period of 30 years. They range from Faculty news to recent developments in his field, and also cover other fields, such as education, ethics and even natural sciences. I am convinced that Piet is probably the colleague with the broadest general knowledge in the Faculty. He is comfortable with a broad range of topics which he is also able to discuss in depth.

All were delighted with his recent betrothal to Riekie van der Walt. They will be getting married sometime during 2010. Those who are close to Piet know what Riekie has meant to him during the past five years or so. We wish them a happy and beautiful marriage.

With this edition of the HTS Theological Studies/Teologiese Studies we bid our colleague and friend farewell. He leaves a significant legacy to both the University of Pretoria and the Netherdutch Reformed Church of Africa. He enjoys the respect and appreciation of those who have shared in his professional journey and this he can treasure. Our prayers accompany him on his way:

The LORD bless and keep thee;

The LORD make his face shine upon thee, and be gracious unto thee;

The LORD lift up his countenance upon thee, and give thee peace.

Johan Buitendag

Chairperson of the Editorial Board 